\title{
CÉLKÖLTSÉGSZÁMÍTÁS ALKALMAZÁSA EGY MEZŐGAZDASÁGI SZERVEZET CONTROLLING RENDSZERÉBEN
}

\author{
Thalmeiner Gergő - Gáspár Sándor
}

\begin{abstract}
Absztrakt: Napjainkban a különböző élelmiszerfogyasztási trendek meghatározzák az élelmiszer ellátási láncok müködését. A trendekre történő hatékony és gyors reagálás egy erős versenyelőnyt biztosít a vállalkozásoknak. Ezen versenyelőny nem feltétlenül az adott trendre történő reagálásban rejlik, hanem a vállalkozások agilitásában. A különböző trendek közül kiemelendő az állatjólét megjelenése az élelmiszeripari termékek fogyasztói preferenciában. Az erre történő reagálás egy bonyolult és komplex kihívást állít a termelők felé. A fogyasztók fizetési hajlandósága és a tartásmódok megváltoztatása az a két tényező, amely ezen kihívásban vizsgálandó tényező lehet. Az állatjóléti szint növelése az állattartó telepeken egy alapvetően beruházás igényes és költségeket növelő tényező. Az állatjóléti szempontból jobb tartásmód kiválasztása és ennek a költség elemzése lehet egyfajta kulcs a tervezés és a megvalósítás során. Ezen tervezés során kifejezetten eredményes módszerként alkalmazható a célköltségszámítás módszertana. Ezen módszertan a fogyasztói értékítéletek és a szervezeti előre definiált profitráta függvényében végzi a költséganalízist. Tanulmányunkban egy kiterjesztett esettanulmány keretében szemléltetjük a célköltségszámítás módszertanának lehetséges alkalmazását egy baromfitenyésztő vállalkozás lehetséges tartásmód váltása során. Kutatásunkban rámutatunk arra, hogy a tartásmódváltás nem feltétlenül profitábilis, és nem minden fogyasztói csoport képes és hajlandó a tartásmódból fakadó többlet költségek megfizetésére.
\end{abstract}

\begin{abstract}
Nowadays, different food consumption trends determine the functioning of food supply chains. Responding efficiently and quickly to trends provides businesses with a strong competitive advantage. This competitive advantage does not necessarily lie in responding to a particular trend, but in the agility of businesses. Among the various trends, the emergence of animal welfare in the consumer preference of food products should be highlighted. Responding to this poses a complicated and complex challenge to producers. Consumers 'willingness to pay and changing attitudes are the two factors that can be examined in this challenge. Increasing the level of animal welfare on livestock farms is a fundamentally investment-intensive and cost-increasing factor. Choosing a better husbandry from an animal welfare point of view and analyzing the cost of this can be a kind of key in planning and implementation. During this planning, the methodology of target cost calculation can be used as an explicitly effective method. This methodology performs cost analysis based on consumer value judgments and organizational predefined profit margins. In our study, we illustrate the possible application of the target cost calculation methodology in the framework of an extended case study when changing the possible husbandry of a poultry farm. In our research, we point out that a change in lifestyle is not necessarily profitable, and not all consumer groups are able and willing to pay the extra costs of a lifestyle.
\end{abstract}

Kulcsszavak: célköltségszámítás, controlling, költségstruktúra, mezőgazdasági szervezet

Keywords: target cost calculation, controlling, cost structure, agricultural organization

\section{Bevezetés}

Az élelmiszerfogyasztást nagymértékben meghatározzák a különböző, társadalmi és kulturális változások. Ezen dinamikus változások kikényszerítik a különböző élelmiszer ellátási láncban tevékenykedő vállalkozások alkalmazkodását a megváltozott fogyasztói igényekhez. A különböző fogyasztási trendek 
meghatározása és kiértékelése egy alapvető fudamentum ezen alkalmazkodás folyamatában. A vállalkozások még ha sikeresek is a rájuk ható piaci trendek megállapításában, az még nem jelenti a sikeres alkalmazkodást (Zsótér-Bagi, 2020). A vállalkozás müködési folyamatai, eszközei, szervezeti struktúrája és etikai hozzáállása az, amit össze kell vetni a piaci trendekkel. A piaci trendekre való reagálás tehát egyfajta költség-haszon elemzésen alapszik.

A különböző költségszámítási módszertanok a múlt adatain alapulnak, és nem veszik figyelembe a fogyasztói igényeket, illetve a technológiai innovációk költségeinek beépülését a rendszerbe. A célköltség módszertana viszont lehetöséget teremt a különböző fogyasztói igények és a fogyasztói értékítélet, illetve fizetési hajlandóság tervezére. Ezáltal ez egy kiváló módszer lehet a megváltozott élelmiszerfogyasztói igények által támasztott elvárások költségelemzésére.

Kutatásukban egy kiterjesztett esettanulmányon keresztül szemléltetjük a fogyasztók állatjólét iránt tanúsított növekvő igényének hatását egy baromfitenyésztő vállalkozás ezen irányú alkalmazkodásának lehetőségeire. Esettanulmányunkban célköltség számítás módszertanával megvizsgáljuk a szervezet tartásmód váltási lehetőségét és az ezzel járó költségeket összevetjük a fogyasztói csoportok többlet fizetési hajlandóságával.

\section{Az élelmiszer-fogyasztásban felmerülő értékrendek}

Roos-Hahn, (2017) szerzőpáros munkássága alapján, az értékrend alapú fogyasztás és az élelmiszer-fogyasztói magatartás elméletének közös fundamentuma, a vevői döntést az értékrendszer külső formájának interpretálják. A fogyasztói magatartás kulcstényezöi közül az egyik legbefolyásolóbb az értékrend, amely a fogyasztói magatartás alapvető eleme. Az értékrend a fogyasztói magatartás belső korrelációs logikáját meghatározó tényezők egyike. Az interdiszciplináris jellegü megközelítés szerint kijelenthetö, hogy az értékrend két környezeti elemhez, kulturális és társadalmi tényezőkhöz köthető. Az értékhez a legtöbb esetben az életmódot, életstílust és státuszdimenziókat kötik hozzá. Ezen dimenziókat a különböző körülmények, szituációk és az egyéni relatív és szubjektív fontosság befolyásolja. Más tanulmányok kiemelik az érték egyéni meghatározottságát, amely során az egyéni szubjektivitás meghatározó. Peter-Olson (1987) tanulmányukban úgy határozzák meg a fogyasztói értéket, mint a fogyasztó alapvető szükségleteinek, elöre meghatározott céljainak kognitív képviselöje. A fogyasztói preferenciák kialakítására, vásárlási döntéshozatalt befolyásoló tényezőinek definiálására számos értékmérő módszer létezik. Ezen módszerek közül számos olyan módszer létezik, amely kifejezetten a táplálkozási, élelmiszerfogyasztási szokásokat különböző értékrend szerint modellezik. Az értékrendalapú élelmiszer-fogyasztói magatartásra vonatkozó elmélet alapján el lehet különíteni három szintet, amelyek között különválik az értékek élelmiszer-fogyasztási preferenciákra gyakorolt hatása. Ezen osztályok között az első a fogyasztó alapvető értékei. A második szinten a fogyasztási szokásokra befolyást gyakorló értékrendek találhatók. Ezen tényezők közé sorolhatók a fogyasztó társadalmi, életkörülményi és preferencia körülmények. A harmadik szinten pedig az adott termékhez társított közvetlen értékek szerepelnek. 
Ezen értékek a termék választáshoz kötődő okokat és különbözö indítékokat tárja fel (Sánchez-Fernández-Iniesta-Bonillo, 2007).

\subsection{Az állatjólét fogyasztói értékítélete}

Az állatok olyan biológiai szervezetek, amelyek megfelelő müködéséhez szükséges a jó egészségi állapot. A megfelelő egészségi állapot megteremtéséhez és megőrzéséhez, az állatok jóléti szükségleteinek kielégítéséhez kapcsolódnak a különböző állatjóléti szempontrendszerek (Goldberg, 2016). Az állatjóléti szempontok az állatok fundamentális szükségleteinek biztosítására fokuszál. Az állatok alapvető szükségletei tartozik az élelemhez, vízhez, természetes fényhez, friss levegőhöz való hozzájutás, pihenéshez szükséges menedék magas szintü biológiai működéshez szükséges megfelelő mozgástér biztosítása, valamint betegség esetén az állatorvosi ellátás biztosítása Az állatok alapvető szükségletei közül fontos megemlíteni a fájdalomtó, szorongástól és szenvedéstől való mentesülést is (Von Keyserlingk et al., 2017).

A haszonállatok jólétére vonatkozó egyre magasabb szintet a különböző hatósági intézkedések és piaci alapú szervezetek kényszerítik ki. Az elmúlt évtizedben számos piaci alapú szabvány, védjegy és tanúsítvány jött létre, amelyek a változó piaci fogyasztói igényeket tükrözi (Mayfield et al., 2007). Ezen elvárások a haszonállatok szenvedésének csökkentését, a különböző gyógyszeres - növekedést felgyorsító antibiotikumos kezelések csökkentését és az állatok jobb életének megteremtését jelentik. A Miranda-de la Lama és szerzőtársai (2016) szerint ezen elvárások mögött az egyik jelentős kiváltó ok a GMO-tól (Genetically Modified Organisms), való félelem és a termelésből adód alacsony állati egészségügyi színvonal jelentős hatása az emberi egészségre.

\subsection{Modern költséganalitikai módszerek}

A felelösségi elvü számvitelnek a gyakorlatban való megjelenése a 1920-1930-as években történt meg. A korai költségszámítási módszerek és rendszerek elsősorban az előállítási költség követését és nyomon követésére fókuszáltak és az elöállítási folyamatokban lévő lekötött erőforrások hatékonyságának mérésére, addig ez az új szemléletben kialakított számvitel más célokkal és relatív értelemben vett magas önállósággal rendelkező, a vállalati felsővezetés által operatív szempontból felügyelhető egységek és teljesítmények kontrollja volt. Ez hívták és hívják vezetői számvitelnek (Zéman, 2016).

A 20. század elején a vállalati méretek növekedtek és velük együtt a szervezetek diverzifikáltsága is és a vállalatok területi széttagoltsága is. Ezek a trendek teremtették meg a lehetőségét és szükségét annak, hogy a vállalatvezetők felülvizsgálják az addig alkalmazott közvetett vállalati irányítási gyakorlatukat (Dobák, 1992).

A vezetői számvitel további alkalmazhatóságának kérdéseit az 1980-as években vetette fel Kaplan (1987) és Johnson (1972). Ök voltak azok, akik megfogalmazták az elveszett lényeg filozófiáját a költséggazdálkodásban, melynek további gazdálkodásszervezésben betöltött szerepét és felemelkedését is kiemelték. 
Ugyanakkor vitatták, hogy a controlling alapjául szolgáló vezetői számvitel a folyamatok belső hatékonyságának figyelembevételével fejlödött volna ki. Anthony-Vijaj (2006) szerint a pénzügyi és vezetői számvitel szétválásának a fő oka az iparvállalatok vezetői információs igényeinek az eltérő mértéke volt, amely egyértelmüen a termék és a hozzá tartozó költség-számításra fókuszált míg, a szolgáltatási termékekkel rendelkező szervezetek más vezetői információs igényekkel rendelkeztek.

Fontos kiemelni, hogy ez a fajta szemlélet az érdekorientációval egyidejüleg alakult ki a vezetői információs igényeket is figyelembe véve, amire pedig a későbbiekben a képviselet-elméletként hivatkoztak. Az 1980-as években a vezetöi számvitel sok hangsúlyos kihívással szembesült, és a fókusz újra a gyártási folyamatokra, a minőség iránti igényre, a terméktervezésre, illetve a számítógéppel ellenőrzött termelési folyamatok bevezetésére szegődött (Blumné-Zéman, 2014). Az új környezeti feltételek mellett számos szervezet szembesült azzal, hogy hagyományos költség-számviteli mércéik nem segítik elő az innovatív termelési eljárások és technológiák bevezetését, így egyértelművé vált, hogy a kialakult gyakorlatra a fentebb már említett gyakorlati teóriák nagyon kevés hatással voltak (Zéman, 2016).

\subsection{Célköltségszámítás}

Az 19. század végén újabb költséganalitikai módszerek jöttek létre. Alapvetően három különböző iskolát lehet elkülöníteni. Az amerikai tevékenység alapú, a német folyamat alapú és a japán célköltségszámítás alapú iskolát.

A 1960-as évektől termék fejlesztési-, tervezési szakaszai költséganalitika aspektusából kiemelten fontossá vált. Ezen szempontokat figyelembevéve a célköltségszámítás olyan menedzsment módszert jelentett, amely fogyasztói igények és fizetési hajlandóság mellett a termék elvárt funkcióit olyan költségekkel tervezi meg, amely az elöre meghatározott profit megszerzését biztosítja (Raman, 2000). Mára a célköltségszámítást széleskörben alkalmazzák, olyan multinacionális szervezetek is, mint például Mercedes, Caterpillar, Panasonic, Apple és Toshiba (Maher et al., 1997).

A célköltségszámítás leghatékonyabban az új termékek bevezetésekor, kifejlesztésekor lehet alkalmazni, illetve a lean szervezeti müködés esetében (Anthony-Vijaj, 2006). A hatékony költségkontroll akkor valósítható meg, ha már a terméktervezési, -fejlesztési szakaszban definiálásra kerül, és nem utólag, a tervek elkészültét vagy termelés beindítása után valósul meg (Mourisen et al., 2001). Ahogy azt az 1. ábra is szemlélteti a célköltségszámítás fogyasztóközpontú, alapfeltevése, hogy mi az a piaci ár, amit a fogyasztók hajlandók kifizetni az elvárt minőségért és funkcióért. Ehhez mérten számolja és allokálja a termék előállításának költségét, hogy egy elöre definiált nyereséget realizálhasson (Horváth-Mayer, 2011). 


\section{1. ábra: Célköltségszámítás folyamata}

Fogyasztói fizetési hajlandóság elemzésén alapuló költséganalízis

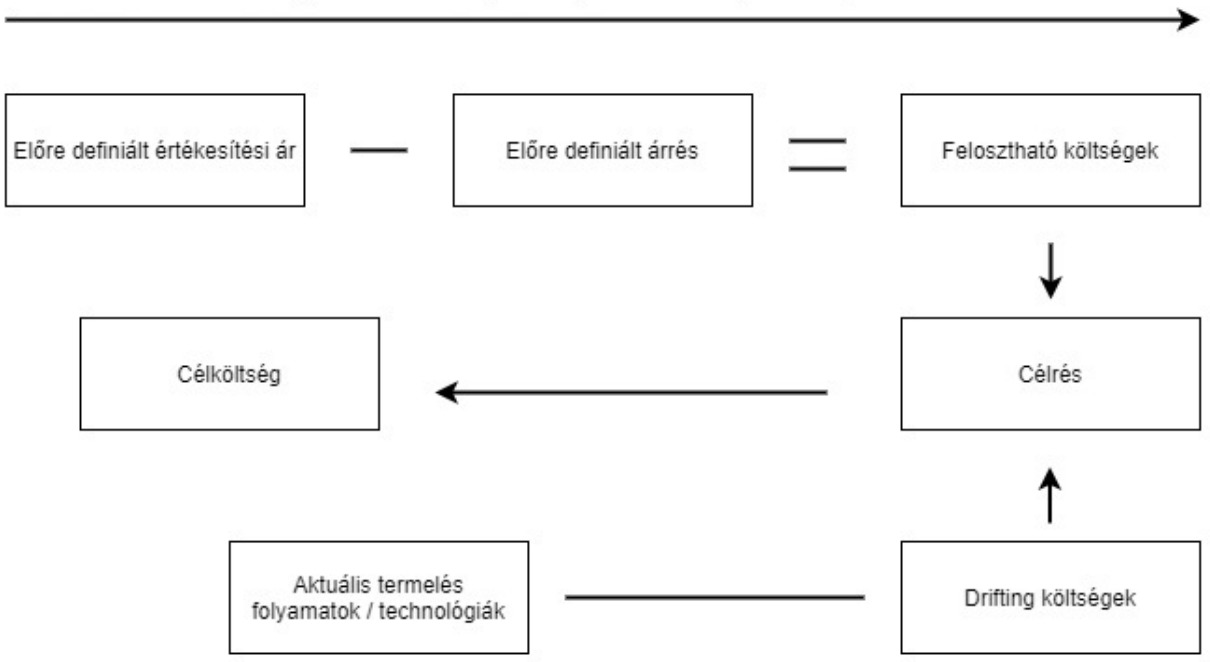

Szervezetek termelési költségeinek elemzésén alapuló költséganalízis

Forrás: A szerzők saját szerkesztése

\section{Anyag és módszer}

Kutatásunk során egy kiterjesztett esetelemzést végeztünk el. Az esettanulmányunk a Bács-Kiskun megyében található baromfitenyésztő vállalkozás szolgált. A vizsgált szervezet fő tevékenysége brojlercsirketenyésztés, amelyet intenzív tartástechnológiai körülmények között valósít meg. A telepen 4 aktív istállóban folyik a termelés, amely során évente megközelítőleg 1,3 millió $\mathrm{kg}$ vágócsirkehúst értékesít.

Azért választottuk a kiterjesztett esetelemzés módszert, hogy felfedezzük a meglévő elméletek, illetve a gyakorlatban alkalmazott módszerek hiányosságait. A gyakorlatban alkalmazott modellt egy adott teoretikus szakirodalomban megfogalmazott módszerek mentén, illetve más empirikus kutatások mentén tovább fejlesztjük különböző struktúrák és adottságok mentén (Babbie, 2013). Célul tüztük ki a célköltségszámítási módszer alkalmazhatóságának vizsgálatát az élelmiszer fogyasztói szokások változására történő reagálás tekintetében.

A fogyasztói preferenciák felmérése érdekében közösen az elemzett vállalkozással egy kvantitatív kutatást végeztünk, egy Magyarországon elvégzett 317 fős fogyasztói mintán, véletlenszerủ mintavétellel. A preferencia felmérés során jelentős hangsúlyt helyeztünk a fogyasztók állatjóléttel kapcsolatos értékítéletére. A kérdőíveket 25 fös mintán teszteltük. A vizsgálathoz kérdőíves kutatást alkalmaztunk. A kérdőív első része a demográfiai és egyéb adatokra, míg a másik fele a fogyasztási szokásokra vonatkozik. A kutatásunk során egy faktorelemzést készítettünk a különböző fogyasztói csoportok elkülönítése érdekében. 


\section{Eredmények}

Az általunk vizsgált szervezet fö tevékenysége a brojler csirketenyésztés, amelyet vágóhíd felé értékesít. A csirketelepen aktívan 4 istállóban folyik a tenyésztés, amelynek köszönhetően a szervezet évente több mint egymillió kg brojlercsirkét értékesít. Ezt a volument a szervezet korszerü technológiája, valamint a kiváló szakértelemmel rendelkező munkavállalók és telepi menedzsment teszi lehetővé. A termelés során komoly figyelmet fordítanak a megfelelő genetikai állomány kiválasztására, valamint a kiváló minőségủ takarmányozási program biztosítására. A kiváló minőségü, többfázisú takarmányozási program nem csak a szigorú minőségi feltételeknek kell megfeleljen, de a legjobban kell illeszkedjen a brojler adott életszakaszaihoz. Ezáltal biztosítható, a megfelelő fejlődés és a teljesítményigény kiszolgálás. A szervezet jelenleg 6 főt foglalkoztat, amelybe a menedzsment tagjai is beletartoznak.

A szervezet az elmúlt évek során komoly fejlesztéseket hajtott végre, amellyel a piaci pozícióját próbálja megőrizni. A fejlesztések közül kiemelendő a technológiai beruházások és fejlesztések jelentősége, amellyel a hatékonyság növelés és a kiegyensúlyozott termelés biztosítása a cél. Továbbá a takarmányozási program folyamatos felülértékelése is rendszeresen megtörténik. Az elmúlt évek során csak kiváló fuzárium és toxin mentes takarmányt használnak. Ezen fejlesztéseket mind a piaci körülmények mind pedig a fogyasztói trendek változása okozta. Ugyanakkor megfogalmazható, hogy az ágazaton belül nagyon intenzív verseny folyik, amelyben a termelők érdekérvényesítő képessége nagyon alacsony. Ebből adódóan a termelési hatékonyság szük keresztmetszetet képez, viszont önmagában a termelés hatékonyságának növelésével és a technológiai fejlesztésekkel még nem érhető el a piaci versenyből való kitűnés.

\subsection{Célköltségszámítás megjelenése}

Az ágazat jövedelmezőségi helyzete nagyon változó. Az elmúlt évek során komoly ár ingadozás figyelhető meg a piacon a vágócsirke termelői árában. Általánosan megfogalmazható, hogy az ágazatra nagyon jelentős globális verseny jellemzö, amely a termelöi árak ingadozásának következtében jelentősen befolyásolja a szervezet rentabilitását. Az élesedő nemzetközi verseny kikényszeríti az ágazat innovációját és a piaci trendek változásának figyelemmel kísérést. A fogyasztói vásárlást befolyásoló tényezők között az állatok jóléti szintjének növelése egyre jelentősebb tényezként figyelhető meg. A kiéleződő piaci tényezők, valamint a fogyasztó trendek változásának figyelemmel kísérése során a szervezet tartástechnológia változtatását mérlegeli. $\mathrm{Az}$ új alternatív tartástechnológia következtében egy istálló átalakítását úgy tervezik, hogy az állatoknak lehetőségük legyen nyitott területre is kimenni az istállóból. Ennek következtében az istálló hasznos alapterülete $1200 \mathrm{~m}^{2}$-röl $1500 \mathrm{~m}^{2}$-re növekedne, tehát kiegészül $300 \mathrm{~m}^{2}$ külső területtel. Az istálló hasznos alapterület növelése pozitív hatást gyakorolhat az állomány fejlődésére és természetes viselkedésének gyakorlására. A szervezet az istálló telepítési mennyiségét nem növeli, így csökkeni fog az egy négyzetméterre jutó állatok száma. 
A szervezet tervezési mechanizmusában tetten érhető a célköltségszámítás középpontjában lévő filozófia, amely szerint a fogyasztói értékből kell kiindulni, ennek megteremtése a cél. Azáltal tehát, hogy a szervezet a fogyasztói igényváltozást figyelemmel kíséri, ami szerint a fogyasztók az állatjólét magasabb színvonalát előnyben részesíti és hajlandó megfizetni ennek a hozzáadott értéknek az árát, a szervezet közvetetten a célköltségszámítás módszertanát alkalmazza. A szervezet az új tartásmód megvalósítása előtt tervezetet készít a termelés naturális értékeire, valamint költségekre vonatkozólag. Ez a jellegü tervezési folyamat jelentős részét képezi a célköltségszámítás módszertanának is, amely során meghatározásra kerül a maximális költség értéke, amely az elöre meghatározott profit függvényében felosztásra kerülhet. Ugyanakkor a szervezet által az elöre meghatározott profit nem jelenik, meg ezért elmondható, hogy a célköltségszámítás módszertanának csak egyes elemeit alkalmazza müködése során.

Ahhoz, hogy értékelni tudjuk a szervezet müködését az alábbi táblázatban szemléltetjük a tevékenységre jellemző adatokat. A szervezet által jelenleg is alkalmazott tartásmód intenzív tartásmódú, tehát a táblázat ezen értékei az aktuálistényleges müködésből adódnak. Az alternatív tartásmódhoz kapcsolódó értékek viszont prognosztizáltak, tehát a jövőbeli müködésre vonatkozó kalkulációs értékek vannak feltüntetve. Az 1. táblázat egy istálló átlagos termelési adatait szemlélteti.

1. táblázat: Naturális mutatók

\begin{tabular}{|l|c|c|c|}
\hline \multicolumn{1}{|c|}{ Megnevezés } & Mértékegység & $\begin{array}{c}\text { Mutatók } \\
\text { tényleges értékei } \\
\text { (Intenzív } \\
\text { tartásmód) }\end{array}$ & $\begin{array}{c}\text { Mutatók } \\
\text { tervezett értékei } \\
\text { (Alternatív } \\
\text { tartásmód) }\end{array}$ \\
\hline Telepítési sürúség & $\mathrm{db} / \mathrm{m}^{2}$ & 18 & 14 \\
\hline Betelepített db & $\mathrm{db}$ & 21600 & 21600 \\
\hline Elhullási százalék & $\%$ & 4,3 & 4,9 \\
\hline $\begin{array}{l}\text { Átlagos } \\
\text { takarmányhasznosulás }\end{array}$ & $\mathrm{kg} / \mathrm{kg}$ & 1,66 & 1,78 \\
\hline Átlagosan elöállított $\mathrm{kg}$ & $\mathrm{kg}$ & 54300 & 54300 \\
\hline Állományforgó & 1 évre & 5,9 & 5,5 \\
\hline
\end{tabular}

Forrás: A szerzők saját szerkesztése

A táblázat adatai alapján elmondható, hogy egyes mutatók értékei jelentősen eltérnek a két tartásmód között. Az alternatív tartásmód kialakítása esetén a telepítési sürüség csökken viszont, az elhalálozási százalék, a takarmányhasznosulás és az állományforgó mutatója kedvezőtlenebb értékkel rendelkezik. $\mathrm{Az}$ adatok figyelembevételével mindkettő tartásmódra vonatkozólag kiszámítható a brojler 
index, amely fontos hatékonysági mérőszám az ágazaton belül. A szervezet az EPEF (European Production Efficiency Factor) mutatót alkalmazza. Az átlagos adatok figyelembevételével és a számítás szemléltetése érdekében történő egyszerüsítésekkel a következőképpen alakul a mutatók értéke (l).

$$
\begin{aligned}
& E P E F=\frac{\text { Életképesség }(\%) \cdot \text { Vágáskori testtömeg }(\mathrm{kg})}{\text { Vágáskori életnap }(\text { nap }) \cdot F \text { ajlagos takarmányhasznosulás }(\mathrm{kg} / \mathrm{kg})} \cdot 100 \\
& E P E F_{\text {intenzív tartási mód }}=\frac{95,7 \cdot 2,66}{44 \cdot 1,66} \cdot 100=348,5 \\
& E P E F_{\text {alternatív tartási mód }}=\frac{95,1 \cdot 2,66}{49 \cdot 1,78} \cdot 100=290,0
\end{aligned}
$$

Az EPEF mutató jól szemlélteti, hogy a két tartástechnológia közül az intenzív tartásmód hatékonyabb, mint a bevezetni kívánt alternatív tartásmód. Ugyanakkor a termelési alapadatok meghatározása mellett szükséges megvizsgálni a termelés költségstruktúráját is, amelyet a 2. táblázat szemléltet. A táblázatban feltüntetett értékek $1 \mathrm{~kg}$ élősúlyra vetítve kerültek meghatározásra.

\section{2. táblázat: Termelési költségstruktúra}

\begin{tabular}{|l|c|c|}
\hline \multicolumn{1}{|c|}{ Megnevezés } & $\begin{array}{c}\text { Tényleges költségek } \\
\text { (Ft/kg) } \\
\text { (Intenzív tartásmód) }\end{array}$ & $\begin{array}{c}\text { Tervezett költségek } \\
\text { (Ft/kg) } \\
\text { (Alternatív tartásmód) }\end{array}$ \\
\hline Takarmány & 129,3 & 151,6 \\
\hline Napos állat & 39,8 & 39,8 \\
\hline Segédanyagok & 3,2 & 4,51 \\
\hline Átlagos energia költség & 10,87 & 9,7 \\
\hline Állategészségügy & 4,12 & 5,82 \\
\hline Alomanyag & 0,83 & 0,83 \\
\hline Bér és járulék & 11,65 & 11,65 \\
\hline $\begin{array}{l}\text { Épület és eszközök } \\
\text { értékcsökkenése }\end{array}$ & 2,4 & 2,8 \\
\hline $\begin{array}{l}\text { Javítási és karbantartási } \\
\text { költségek }\end{array}$ & 1,15 & 1,72 \\
\hline Igénybe vett szolgáltatások & 5,4 & 5,4 \\
\hline $\begin{array}{l}\text { Takarítás + } \\
\text { anyagköltségek }\end{array}$ & 1,73 & 2,23 \\
\hline Állati hulla kezelés & 0,8 & 1,2 \\
\hline Egyéb közvetlen költségek & 1,9 & 2,3 \\
\hline Fix költségek & 3,2 & 3,2 \\
\hline Összesen & $\mathbf{2 1 6 , 4}$ & $\mathbf{2 4 4 , 4 9}$ \\
\hline
\end{tabular}

Forrás: A szerzők saját szerkesztése 
Az adatok alapján megállapítható, hogy az intenzív tartásmódban egy kg élőtömeg előállítása során megközelítőleg 216 Ft költség képződik. Amennyiben ezt az istálló teljes állományra vetítjük, akkor elmondható, hogy átlagosan 11,8 millió Ft szükséges. Ezzel szemben az alternatív tartásmódban egy kg élőtömeg előállítása során megközelítőleg 244 Ft költség képződik, ami az istálló teljes állományra vetítve 13,4 millió Ft-ot jelent. A táblázat adatai alapján elmondható, hogy a legjelentősebb változás a takarmányköltség növekedésében jelenik meg. Ez a növekedés nem csak a tartásmód váltásból adódik, hanem abból is, hogy a szervezt a takarmányösszetétel változtatását is tervezi, amely során csak GMO mentes komponenseket fognak használni. Továbbá az állati fehérje (halliszt) használata teljesmértékben kikerül a takarmánykomponensek közül. Az állategészségügyi költségek is megnövekednek, mivel a nyitott tér használatával, valamint a négyzetméterenkénti sürüség csökkenésével az állatok aktívabbak lesznek ezáltal megnövekszik a sérülések száma is, ami végső soron elvezet az elhullási mutató értékének növekedéséhez.

A naturális mutatók és költségtényezők vizsgálatát követően a tartásmódok jövedelmezőségének kalkulálása és összevetése alapján lehet döntést hozni a tartásmódok eredményességéröl. A szervezet a vizsgált időszakban az intenzív tartásmódban tartott brojlercsirkéket $263 \mathrm{Ft} / \mathrm{kg}$-os áron értékesítette. Az alternatív tartásmód megvalósítása esetén ennél magasabb átvételi árral lehet kalkulálni. A szervezet az egy kg-ra jutó profitrátát nem követi nyomon. Azért, hogy a jövedelmezőségét összehasonlíthassuk az alábbiakban megvizsgáljuk a két termelési mód profitrátáját. Az intenzív tartásmód esetében a mutató meghatározásához rendelkezésre állnak a tényleges adataink, viszont a megvalósítani kívánt alternatív tartásmód esetében az értékesítési árat a fogyasztói átlagos fizetési hajlandóság segítségével határozzuk meg (2).

Egy kg-ra jutó profit rátaintenzív tartási mód $=\frac{263-216,4}{263} \cdot 100=17,7 \%$

Egy kg-ra jutó profit ráta alternatív tartási mód $=\frac{316-244,49}{316} \cdot 100=22,6 \%$

A tartásmódok profitrátáinak összehasonlítása során megállapítható, hogy a szervezet több profitot tudna realizálni az új tartásmód bevezetésével, azonban fontos figyelembe venni a kibocsátott mennyiség csökkenését, amely jelentősen csökkentheti a teljes szervezeti profit értékét. Abban az esetben, ha sikeresen implementálni tudja a szervezet az új tartásmódot és azt hatékonyan tudja müködtetni meghatározhatóvá válhat egy szervezeti szintü kibocsátási mennyiség, ami mellett a szervezet a jelenleg alkalmazott intenzív tartásmódnál jövedelmezőbb müködést tud kialakítani. Ennek megvalósítása érdekében azonban szükséges a jelenleg tervezett projekt megvalósítása és a termelésre vonatkozó szükkeresztmetszetü tényezők feltárása. 


\subsection{Fogyasztói fizetési hajlandóság}

A fogyasztói fizetési hajlandóságot kérdőíves felméréssel mértük fel. Az elemzés során faktorelemzést készítettünk, amelyek alapján körvonalazódik a fogyasztási preferenciák alakulása és a fizetési hajlandóság mértéke. Az elemzést követően a 3. táblázat alapján kijelenthető, hogy három jól elkülönülő faktor jött létre, amelyek a rotálást követően jól azonosítható és pozícionálható csoportokat képeznek. A három faktor magyarázó ereje 63,5\% a teljes varianciára nézve. Az elemzés során néhány változót ki kellett zárni, ezt követően pedig a statisztikai próbálkozások során létrejött a három faktor. Az eredmények alapján az első faktort az ,állatjólét iránt elkötelezett fogyasztók"-nak neveztük el. Ezen faktoron belül elvárás a magas állatjóléti színvonal, valamint a fizetési hajlandóság is magas. Ezen csoport válaszadói jóval magasabb árat hajlandóak fizetni ezekért a termékekért. A második faktor az ,állatjóléti szempontból befolyásolhatók” kategóriája. Ez a csoport nagyon érdekes változókat tekint fontosnak. Ezen kategória válaszadói kifejezetten hangsúlyosnak tekintik a haszonállatok jólétét, viszont ezzel szemben nem mutatnak akkora hajlandóságot a többletfizetésre. Az állatjólét szintjének növelését nem csak az állatok szenvedése miatt tartják fontosnak, hanem az emberi egészséget befolyásoló hatása miatt is. A harmadik csoport a ,állatjóléti szempontból érdektelen" névvel jellemezhető. Ezen csoporton belüli fogyasztók előnyben részesítik, és alapvetőnek tartják a húsfogyasztást a mindennapokban. A legtöbbjük tart, vagy tartott háztartásán belül haszonállatokat, viszont az állatjóléti szempontokkal szemben nem mutat érdeklődést. Ezen csoport egyik legfontosabb jellemzője az, hogy nem hajlandó a többletfizetésre a magasabb állatjóléti szinttel rendelkező állattartó telepekről származó élelmiszerekért. A három csoport fizetési hajlandóságát értékelve megfogalmazható, hogy az első faktorba válaszadók jelentősen hajlandóak a többletfizetésre, akár $50 \%$-os felárat is megfizetnének. A második csoport válaszadói közel 20\%-os felárfizetési hajlandóságot jelöltek meg, míg az utolsó faktorba tartozó válaszadók fogyasztásuk során nem fizetnének többet a magasabb állatjóléti színvonallal rendelkező termékekért.

Összességében megállapítható, hogy az állattenyésztés egyre több olyan politikai és társadalmi elvárással szembesül, amelyek messze túlmutatnak az alapvető állatjóléti színvonal biztosításán. A környezetvédelem, a GMO mentes termékek részarányának növekedése, a mezőgazdasági és élelmiszeripari termékek nyomonkövetési igénye, valamint az egészségestudatos táplálkozás új kihívások elé állítja az ágazatot. Ahhoz, hogy a szervezetek ezen követelményeket gazdaságosan teljesíteni tudják, az intézkedéseiket úgy kell végrehajtaniuk, hogy figyelembe veszik a gazdasági kritériumokat. Az egyre súlyosabb gazdasági nyomással szembesülő szervezetek számára a célköltségszámítás hatékony módszerként szolgálhat arra, hogy a fogyasztói igények változása mellett elérjék az előre meghatározott profitot és ehhez megfelelő költségstruktúrát építsenek ki. 


\section{3. táblázat: Rotált faktormátrix az élelmiszer fogyasztás szempontjaival összefüggő kérdések alapján (n=317)}

\begin{tabular}{|c|c|c|c|}
\hline \multirow{2}{*}{ Élelmiszer fogyasztás szempontjai } & \multicolumn{3}{|c|}{ Faktorok } \\
\hline & Elkötelezettek & Befolyásolhatók & Érdektelenek \\
\hline $\begin{array}{l}\text { Minden étel-ital vásárlás során törekszem az állatjóléti címkével } \\
\text { rendelkező termék vásárlására }\end{array}$ & 0,696 & $-0,113$ & 0,168 \\
\hline $\begin{array}{l}\text { Ha megtudnám hogy nem felel meg az adott élelmiszeripari márka-vállalkozás az } \\
\text { állatjóléti szabványoknak nem vásárolnék soha többet töle. }\end{array}$ & 0,546 & $-0,137$ & 0,282 \\
\hline $\begin{array}{l}\text { Hajlandó lennék akár } 50 \% \text {-al is többet fizetni a különböző állati } \\
\text { eredetű élelmiszeripari termékekért ha azok garantáltan megfelelnek a legmagasabb } \\
\text { állatjóléti szabványoknak }\end{array}$ & 0,524 & $-0,057$ & $-0,036$ \\
\hline Inkább előnyben részesítem a BIO termékeket. & 0,522 & 0,285 & $-0,111$ \\
\hline $\begin{array}{l}\text { Ha felhívják a figyelmemet akkor szívesen vásárolok inkább állatjóléti címkével } \\
\text { rendelkező terméket. }\end{array}$ & $-0,001$ & 0,638 & $-0,069$ \\
\hline Volt hogy már nem ettem húst mert sajnáltam az állatot. & $-0,07$ & 0,574 & $-0,055$ \\
\hline Az egészséges életmód miatt elkerülhetetlen a haszonállatok jólétének javitása. & 0,115 & 0,512 & 0,214 \\
\hline $\begin{array}{l}\text { Hajlandó lennék akár } 15 \% \text {-al is többet fizetni a különböző állati } \\
\text { eredetű élelmiszeripari termékekért ha azok garantáltan megfelelnek a legmagasabb } \\
\text { állatjóléti szabványoknak }\end{array}$ & 0,096 & 0,475 & 0,227 \\
\hline Fontos számomra hogy ne egyek minden nap hústerméket. & $-0,101$ & 0,402 & 0,292 \\
\hline Fontos számomra hogy minden nap egyek hústerméket. & 0,073 & 0,087 & 0,389 \\
\hline Tartok otthon haszonállatot. & $-0,14$ & 0,094 & 0,374 \\
\hline Vásárlásaim során elsődlegesen az ár az ami befolyásol & 0,004 & 0,138 & 0,362 \\
\hline $\begin{array}{l}\text { Nem fizetnék többet a különöbző állati eredetű élelmiszeripari termékekért ha } \\
\text { azok garantáltan megfelelnek a legmagasabb állatjóléti szabványoknak. }\end{array}$ & $-0,034$ & $-0,195$ & 0,359 \\
\hline
\end{tabular}

Forrás: A szerzők saját szerkesztése

\section{5. Összefoglalás}

Kutatásunkban szemléltettük egy kiterjesztett esettanulmányon keresztül a célköltségszámítás lehetséges alkalmazási módszertanát egy baromfitenyésztő vállalkozás tartásmód váltása során. Az eredmények rávilágítanak arra a tényre, hogy a magasabb állatjóléttel rendelkező élelmiszeripari termékek iránti kereslet elég jelentős a hazai piacon is. A különböző fogyasztói csoportok viszont más és más többlet fizetési hajlandósággal rendelkeznek ezen termékek irányába. A különböző csoportok által többletfizetési hajlandóságból származó haszon és a tartásmód váltásból fakadó költségek elemzése után kijelenthető, hogy csak az állatjólét iránt a legelkötelezettebb csoport hajlandó akkora felárat fizetni az állatjóléti termékekért, amely esetében jelentős haszonnal járna a tartásmód váltás.

Kijelenthető, hogy a magasabb állatjóléttel rendelkező élelmiszeripari termékek iránti kereslet jelentős a fogyasztók körében, de a fizetési hajlandóság átlagosan még nem annyira jelentős, hogy ezen elvárást minden esetben megfizessék. A szervezet által tervezett tartásmód váltás jelentős költségekkel jár, és az egy csirkére jutó teljes költség is jelentősen nő. Ugyanakkor a fogyasztói fizetési hajlandóság változásának hatása ezen tartásmód változtatást rentábilissá teheti. A szervezet a bevezetni kívánt tartásmód tervezése során számos olyan módszert alkalmazott, amelyek megegyeznek vagy részei lehetnek a célköltségszámításnak. Azonban jelentős eltérés adódik abban, hogy a célköltségszámítástól eltérően a szervezt nem egy általa elöre meghatározott profitrátát definiált és ebből kiindulva határozta meg a 
költségeket az eladási ár függvényében. Hanem elöször a költségek tervezésére kerül sor, majd pedig ebböl adódóan kerül kiszámításra a várható profitráta.

A különböző állatjóléthez kötődő kötelező szabályozási intézkedések hatása is jelentős költségeket róhat a vállalkozásokra, viszont a fogyasztók ezt nem hajlandóak megfizetni. További kutatási lehetőségként fogalmazható meg a legelkötelezettebb csoport részletes vizsgálata, elemzése és az arányuk mértéke a társadalomban, illetve kvalitatív módszerekkel feltárni a pontosabb fizetési hajlandóságok ok-okozati összefüggéseit. Ezen kívül érdekes kutatás lehet a célköltség alkalmazási lehetőség széleskörübb vizsgálata az állattartó telepek innovatív beruházásai esetében is.

\section{Köszönetnyilvánítás}

„AZ INNOVÁCIÓS ÉS TECHNOLÓGIAI MINISZTÉRIUM ÚNKP-20-3-I KÓDSZÁMÚ ÚJ NEMZETI KIVÁLÓSÁG PROGRAMJÁNAK A NEMZETI KUTATÁSI, FEJLESZTÉSI ÉS INNOVÁCIÓS ALAPBÓL FINANSZÍROZOTT SZAKMAI TÁMOGATÁSÁVAL KÉSZÜLT.”

\section{Irodalomjegyzék}

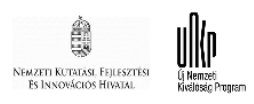

Anthony, R., Vijaj, G. (2006): Management Control Systems. New York, McGraw-Hill Education.

Babbie, E. (2013): The practice of social research (13th. edition.). USA Belmont: Wadsworth, Cengange Learning.

Blumné B. K., Zéman Z. (2014): Controlling a vezetés szolgálatában. Történeti fejlődés, perspektívák. Gazdálkodás- és szervezéstudományi folyóirat, A Virtuális Intézet Közép-Európa Kutatására Közleményei, 6 (1-2): 440-442.

Dobák M. (1992): A diviziónál szervezet. Közgazdasági és Jogi Könyvkiadó, Budapest.

Goldberg, A. M. (2016): Farm Animal Welfare and Human Health. Curr Envir Health Rpt., 3: 313321. https://doi.org/10.1007/s40572-016-0097-9

Horváth P., Mayer, R. (2011): Was ist aus der Prozesskostenrechnung geworden? Controlling and Management Review, 2 (3): 4-30.

Johnson, T. H. (1972): Early cost accounting for internal management controll: Lyman Mills in the 1850. Business Histroy Review, 466-474.

Kaplan, R. S. (1987): Research cultrures in managerial accounting: empicical research. Accounting and culture. McGraw-Hill Education, New York.

Maher, M. W., Stickney, C. P., Weil, R. L. (1997): Managerial Accounting: An Introduction to Concepts, Methods, 6th ed., Harcourt Brace, Orlando, FL.

Mayfield, L., Bennett, R., Tranter, R., Wooldridge, M. (2008): Consumption of Welfare-Friendly Food Products in Great Britain, Italy and Sweden, and How It May Be Influenced by Consumer Attitudes To, and Behaviour Towards, Animal Welfare Attributes. International Journal of Sociology of Food and Agriculture, 15 (3): 59-73.

Miranda-de la Lama, G. C., Estévez-Moreno, L. X., Sepúlveda, W. S., Estrada-Chavero, M. C., Rayas-Amor, A. A., Villarroel, M., María, G. A. (2016): Mexican consumers' perceptions and attitudes towards farm animal welfare and willingness to pay for welfare friendly meat products. Meat Science, 125: 106-113. https://doi.org/10.1016/j.meatsci.2016.12.001

Mourisen, J., Hansen, A., Hansen, C. O. (2001): Inter-organizational controls and organizational competencies: Episodes around target cost management/functional analysis, and open book accounting. Management Accounting Research, 12 (2): 221-244.

Peter, J. P., Olson, J. C. (1987): Consumer Behavior. Homewood, III.: Irwin.

Raman, R. (2000): Target Costing. In: Swamidass, P.M. (szerk.): Innovations in Competitive Manufacturing. Springer, Boston, MA. 399-405. https://doi.org/10.1007/978-1-4615-1705-4_1 
Roos, D., Hahn, R. (2017): Understanding Collaborative Consumption: An Extension of the Theory of Planned Behavior with Value-Based Personal Norms. Journal Business Ethics, 158: 679-697. https://doi.org/10.1007/s10551-017-3675-3

Sánchez-Fernández, R., Iniesta-Bonillo, M. Á. (2007): The concept of perceived value: A systematic review of the research. Marketing Theory, 7 (4): 427-451. https://doi.org/10.1177/1470593107083165

Von Keyserlingk, M. A. G., Weary, D. M. (2017): A 100-Year Review: Animal welfare in the Journal of Dairy Science - The first 100 years. Journal of Dairy Science, 100 (12): 10432-10444 https://doi.org/10.3168/jds.2017-13298

Zéman Z. (2016): A kontrolling fejlődésének főbb irányzatai. Társadalom és Gazdaság, 2 (1): 7792.

Zsótér B., Bagi B. (2020): Gyümölcsfeldolgozó üzem létesítésének pénzügyi elökészületei, Jelenkori Társadalmi és Gazdasági Folyamatok, 15 (1-2): 125-130. 